\title{
24. ORGANIC GEOCHEMISTRY OF NEOGENE SEDIMENTS FROM THE WALVIS RIDGE, DEEP SEA DRILLING PROJECT LEG 741
}

\author{
Philip A. Meyers and Sushiel R. Keswani, Oceanography Program, Department of Atmospheric and Oceanic Science, \\ The University of Michigan, Ann Arbor, Michigan
}

\begin{abstract}
Two samples of Miocene sediments from Site 525 and four samples of sediments ranging in age from Pleistocene to Miocene from Site 528 have been analyzed for concentrations of organic and carbonate carbon, carbon/nitrogen ratios of organic matter, and extractable hydrocarbons and fatty acids. Organic carbon concentrations average $0.32 \%$ and show a diagenetic decrease with greater sediment age. Distributions of $n$-alkanes and $n$-alkanoic acids give evidence of considerable microbial reworking and of eolian contributions of terrigenous components. Organic contents of these sediments reflect a history of low marine productivity and poor preservation of organic matter in the eastern South Atlantic since middle Miocene times.
\end{abstract}

\section{INTRODUCTION}

The organic carbon content of oceanic sediments provides a record of the history of the origin and deposition of biogenic sediments over geological time. The amounts and types of organic components reflect the processes particularly important to the accumulation of organic matter in sediments: its production, transport, and preservation.

Production of marine organic matter depends principally upon the growth of photosynthetic phytoplankton. Changes in their abundance will be recorded as changes in the organic content of sediments deposited over time. Much of the original organic matter is remineralized while sinking through the upper few hundred meters of the oceans (Suess, 1980; Suess and Müller, 1980; Knauer and Martin, 1981). Only the more resistant components reach the sediment surface, and they are but a residual fraction of the initial material produced by phytoplankton.

Superimposed upon the patterns of marine organic matter production is the record of land-derived input to oceanic sediments. Rivers transport the debris of terrigenous plants to coastal areas of the ocean, and winds carry dust particles and their associated organic content to all parts of the seas. For instance, continentally derived lipids have been detected on airborne particulates over the Atlantic (Simoneit, 1977) and the Pacific oceans (Gagosian et al., 1981).

Preservation of organic matter is influenced by factors such as rate of sinking from the surface to the bottom, oxygen content of the water column, benthic microbial activity, and sediment burial rates. In addition, postdepositional diagenesis further alters the composition and amount of sedimented organic matter.

Evidence of organic matter origins and of alteration processes is often recorded in the elemental, isotopic,

\footnotetext{
${ }^{1}$ Moore, T. C., Jr., Rabinowitz, P. D., et al., Init. Repts. DSDP, 74: Washington (U.S. Govt. Printing Office).
}

and molecular composition of the organic fraction of marine sediments. From such information, paleoenvironmental inferences can be made. With this as a goal, it is important to study the organic compositions of sediments lean in organic matter as well as those that are rich in organic matter.

In order to identify the sources of organic matter in sediments and to characterize depositional paleoenvironments in the South Atlantic during the Neogene, samples of sediments were obtained from two locations on the Walvis Ridge occupied during DSDP Leg 74. Analyses were done of organic carbon concentrations, $\mathrm{C} / \mathrm{N}$ ratios of organic matter, and extractable lipid components. Fatty acids and aliphatic hydrocarbons were separated from the extractable lipids and analyzed.

\section{METHODS}

Samples were selected from the frozen core sections preserved for organic geochemical investigations. Two samples from Hole 525A $\left(29^{\circ} 04^{\prime} \mathrm{S}, 02^{\circ} 59^{\prime} \mathrm{E}, 2467 \mathrm{~m}\right.$ water depth), one from Hole 528 $\left(28^{\circ} 31^{\prime} \mathrm{S}, 02^{\circ} 19^{\prime} \mathrm{E}, 3800 \mathrm{~m}\right.$ water depth), and three from Hole 528A ( $3815 \mathrm{~m}$ water depth) were studied. The samples arrived at the laboratory in good frozen condition and were stored at $-20^{\circ} \mathrm{C}$ until analysis began.

After the samples had been freeze-dried, total carbon content was measured with a Hewlett-Packard 185B CHN Analyzer. Residual carbon was measured after $\mathrm{HCl}$ dissolution of carbonates and was considered to represent the total organic carbon content. The percentage of calcium carbonate was calculated from the difference between initial and residual carbon contents. Organic-matter $\mathrm{C} / \mathrm{N}$ atomic ratios were determined from residual-carbon $\mathrm{CHN}$ values. The percentage of organic carbon contents of the samples was calculated on a dryweight basis for the original carbonate-containing sediment.

Lipids were extracted from the freeze-dried sediment by shaking it with toluene/methanol after adding $1 \mathrm{~N} \mathrm{HCl}$ to dissolve biogenic carbonates. Extracted sediment was later treated with $6 \mathrm{~N} \mathrm{HCl}$ to dissolve more resistant carbonates as an independent determination of inorganic carbon content. Extracts were treated with methanolic boron trifluoride to convert fatty acids to their methyl esters, and then lipid subfractions were separated by column chromatography on silica gel. The classes so obtained contained alkanes and alkenes, aromatic hydrocarbons, fatty acid methyl esters, and hydroxy lipids, including sterols and alkanols. Alkane and alkanoic acid results are given in this report.

Splitless injection gas-liquid chromatography was employed to determine the types and amounts of compounds comprising the lipid 
subfractions. A Hewlett-Packard 5830 FID gas chromatography equipped with a $20 \mathrm{~m}$ SE54 glass capillary column was used with hydrogen as carrier gas. Quantification was not attempted because of the low concentrations of organic matter in these samples. Individual fatty acids and hydrocarbons were tentatively identified by retention times in this preliminary survey of the lipid character of these sediments. Combined gas chromatography-mass spectrometry on a Hewlett-Packard 5993 GC-MS equipped with a 50 m SE54 glass capillary column was done on the combined hydrocarbon fractions from Site 528 to rule out nonhydrocarbon components in these sample fractions. Distributions of alkanes and alkanoic acids have been corrected for the minor amounts of laboratory contamination found and for the mass discrimination which occurs over the range of molecular weights surveyed.

\section{RESULTS AND DISCUSSION}

\section{Organic Carbon and $\mathrm{C} / \mathrm{N}$ Values}

The concentrations of total organic carbon in these sediments from the late Tertiary and early Quaternary period are given in Table 1. The mean concentration of organic carbon is $0.32 \%$, which is close to the mean value of $0.2 \%$ found in modern deep sea sediments (Degens and Mopper, 1976) and is in good agreement with mean of $0.3 \%$ in older deep sea sediment samples analyzed from DSDP Legs 1 through 31 (McIver, 1975). Concentrations become smaller as sediment age increases, as also reported in other DSDP samples (Rullkötter, et al., 1980; Waples and Sloan, 1980), and this pattern evidently reflects continued degradation of organic matter.

Low organic carbon content in these Leg 74 samples permits several paleoceanographic conclusions. Low concentration is usually a result of the incorporation of organic matter into the sediments under oxygenated bottom-water conditions that have resulted in poor preservation of organic carbon (Hinga et al., 1979; Cobler and Dymond, 1980; Demaison and Moore, 1980). Low biological productivity in the surface waters of this region of the eastern South Atlantic (Walvis Ridge) during the late Tertiary and early Quaternary period could also account for the low organic matter content of these sediments. These possibilities are similar to those inferred from analyses of Pliocene and Pleistocene sediments from DSDP Leg 72 from the western South Atlantic (Meyers and Dunham, in press).

Judging by the relatively high carbonate values in Table 1, all the sites appear to be above the calcite compensation depth, and there has been little loss of carbonate material. About half of this carbonate appears to be present as dolomite or some similarly resistant carbonate, as indicated by the rate of destruction by $1 \mathrm{~N}$

Table 1. General descriptions and organic contents of samples from Leg 74 sites on the Walvis Ridge, South Atlantic Ocean.

\begin{tabular}{|c|c|c|c|c|c|}
\hline $\begin{array}{c}\text { Sample } \\
\text { (interval in cm) }\end{array}$ & $\begin{array}{l}\text { Sub-bottom } \\
\text { Depth } \\
\text { (m) }\end{array}$ & Age & $\underset{(\%)}{\mathrm{CaCO}_{3}}$ & $\begin{array}{l}C_{\text {org }} \\
(\%)\end{array}$ & $\begin{array}{c}\text { Atomic } \\
\mathrm{C} / \mathrm{N}\end{array}$ \\
\hline $525 \mathrm{~A}-6-5,120-125$ & 105.8 & late Miocene & 70 & 0.75 & 8.8 \\
\hline $525 \mathrm{~A}-8-6,120-125$ & 183.3 & mid-Miocene & 74 & 0.15 & 5.8 \\
\hline $528-1-3,120-125$ & 4.2 & Pleistocene & 76 & 0.38 & 8.1 \\
\hline $528 \mathrm{~A}-5-2,120-125$ & 18.8 & Pliocene & 80 & 0.20 & 10.8 \\
\hline $528 \mathrm{~A}-14-2,120-125$ & 58.4 & Pliocene & 67 & 0.21 & 3.1 \\
\hline $528 \mathrm{~A}-23-2,120-125$ & 98.0 & late Miocene & 67 & 0.16 & 4.5 \\
\hline
\end{tabular}

$\mathrm{HCl}$, only $30 \%$. Treatment with $6 \mathrm{~N} \mathrm{HCl}$ resulted in an additional $35 \%$ loss in initial weight of the sediment sample. These carbonate contents imply low opal contents. Because high concentrations of organic carbon and opal in sediments imply high productivity because of surface upwelling (Diester-Haass, 1978), the low concentrations in these Leg 74 samples thus suggest low productivity since middle Miocene times.

Atomic $\mathrm{C} / \mathrm{N}$ ratios average 6.85 in these six samples, but the values found in individual cases differ substantially, from 3.1 to 10.8 . This variability could be attributed to postdepositional diagenesis (Waples and Sloan, 1980). Surficial marine sediments usually have $\mathrm{C} / \mathrm{N}$ ratios between 9 and 18 (Stevenson and Cheng, 1972; Müller, 1977); thus lower values could indicate greater diagenetic losses of carbon than of nitrogen. Presence of inorganic ammonium and organic nitrogen compounds sorbed on clay minerals, however, can also produce artificially low $\mathrm{C} / \mathrm{N}$ ratios in samples lean in organic carbon (Müller, 1977). Hence, use of $\mathrm{C} / \mathrm{N}$ ratios as indicators of sources of bulk organic matter in such samples could be misleading and is not attempted for these Walvis Ridge sediments.

\section{Aliphatic Hydrocarbons}

Histograms showing the $n$-alkane distributions normalized to the major $n$-alkane are shown in Figure 1. If the exceptional contributions of the $\mathrm{C}_{24}$ component are ignored, Pleistocene and Pliocene samples exhibit trimodal distributions, with maxima at $C_{17}$ or $C_{19}$, at $C_{25}$, and at $\mathrm{C}_{29}$ or $\mathrm{C}_{31}$. These distributions are similar to those found in Quaternary through early Pliocene sediments from DSDP Site 467 on the California Continental Borderland (Simoneit and Mazurek, 1981). Miocene samples show bimodal distributions in Figure 1, the maxima being around $\mathrm{C}_{19}$ and $\mathrm{C}_{29}$. The sources of $n$-alkanes shorter than $\mathrm{C}_{26}$ are primarily degraded microbial detritus of an autochthonous nature; $n$-alkanes longer than $\mathrm{C}_{26}$ originate from allochthonous land plant waxes (Simoneit, 1978). Hence, these Leg 74 hydrocarbon distributions show substantial contributions of terrigenous material, especially in the younger sediments, but the major contributions appear to be from marine sources.

Terrigenous lipids may be transported to these Walvis Ridge locations in association with airborne dusts or by surface ocean currents, but bottom turbidity flows seem unlikely to be important in view of the distance from land and the lower areas of the seafloor between these sites and Africa. Discussions by Simoneit (1977) and Gagosian et al. (1981) of terrigenous lipids found on dust particles collected over the ocean show the probable importance of this process in transporting land-derived organic matter to open-ocean areas, and it is likely that eolian inputs have contributed to the $n$-alkane distributions present in these Walvis Ridge sediments.

A representative chromatogram of the aliphatic hydrocarbon content of these Neogene Leg 74 sediments is presented in Figure 2. This Pliocene sample (528A-14-2, $120-125 \mathrm{~cm}$ ) contains a wide molecular weight range of resolved hydrocarbons and a substantial unresolved complex mixture (UCM) of hydrocarbons having a maximum at $\sim n-C_{20}$. None of the hydrocarbon chromato- 

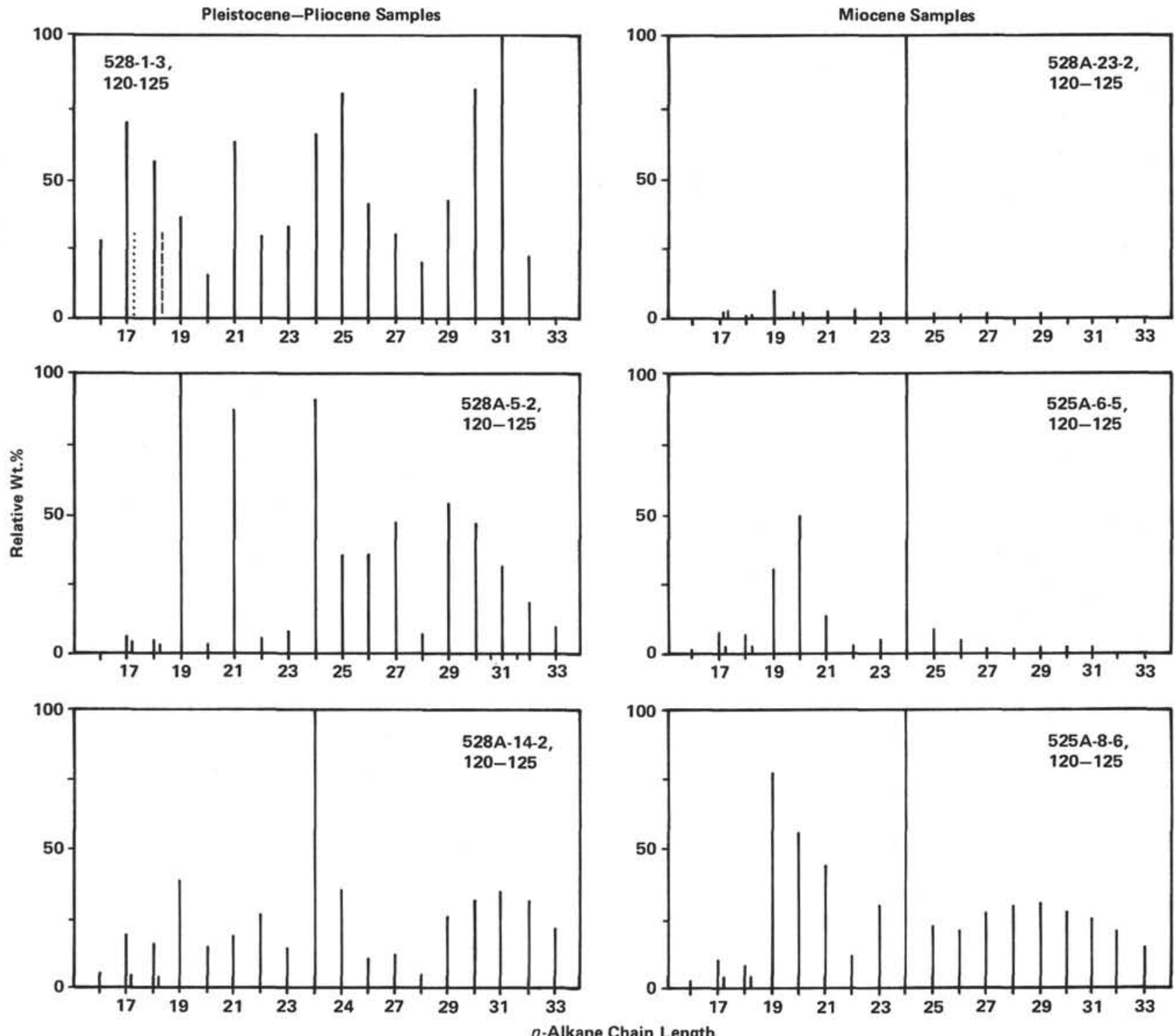

Figure 1. Histograms of aliphatic hydrocarbon distributions normalized to the major component in each sample (100\%). Pristane is indicated by a dotted line; phytane by a dashed line. The large contribution of the $\mathrm{C}_{24}$ component is due to an unidentified branched/cyclic hydrocarbon.

grams resembles those of potential shipboard contaminants (cf. Doran and Johnson, 1979), although all contain a UCM. In view of the ages of these samples and their mild thermal history, the UCMs probably originate from microbial reprocessing of sedimentary organic matter or from older detrital organic material of continental origin which has been incorporated into these sediments.

Ratios of various aliphatic hydrocarbon components are given in Table 2. Pristane/phytane ratios are generally close to unity, which may indicate incomplete euxinic conditions (Didyk et al., 1978), where the rate at which organic matter was added did not fully deplete the oxygen in near-bottom waters (Simoneit and Mazurek, 1981). If these sediments contain a significant portion of recycled hydrocarbons from geologically older deposits, however, then these pristane/phytane ratios may not adequately reflect the actual conditions under which the sediments accumulated. The higher pristane/ phytane ratio of Sample 528A-14-2, 120-125 cm indicates deposition under oxic conditions (Didyk et al., 1978) and may be the most representative paleoenvironmental value. Ratios of pristane to $n-\mathrm{C}_{17}$ are consistently less than one and suggest microbial contributions to the hydrocarbon contents of the sediments. This inferred microbial input agrees with other geolipid characteristics in the Leg 74 samples. Ratios of $n-\mathrm{C}_{29}$ to $n-\mathrm{C}_{17}$ alkanes are presented as a measure of allochthonous, land-derived hydrocarbons to those of autochthonous, marine origin. Lack of any systematic pattern in this ratio suggests variations in the sources of organic matter and in the depositional environments at these two Walvis Ridge sites since middle Miocene times.

Large contributions of a $\mathrm{C}_{24}$ component are shown in the aliphatic hydrocarbon distributions in Figure 1 and in the chromatogram in Figure 2. Such dominance of an even-chain-length $n$-alkane is exceptional in sediments, although large contributions of $n-\mathrm{C}_{24}$ have been report- 


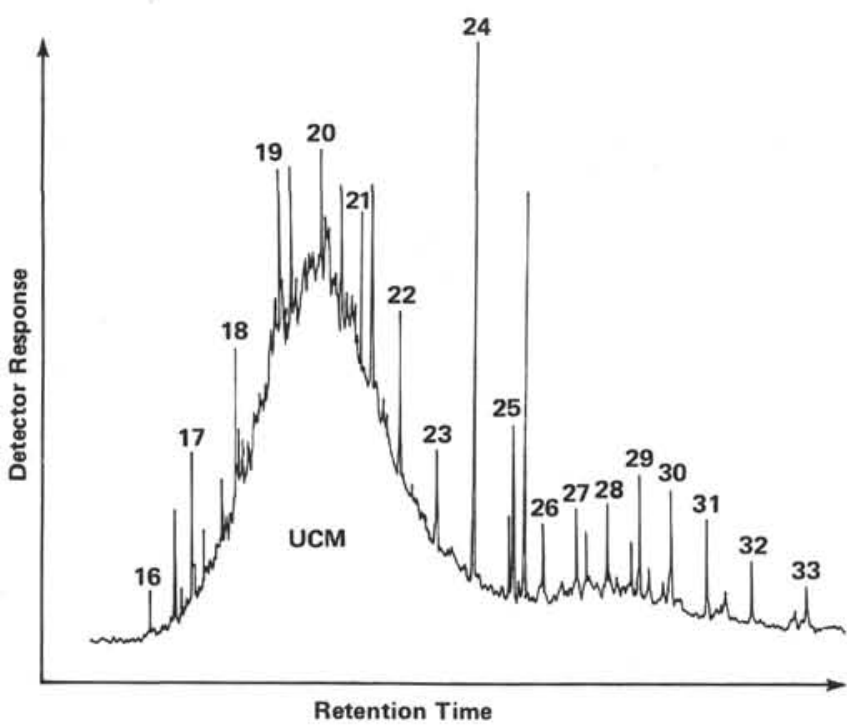

Figure 2. Chromatogram of the aliphatic hydrocarbon fraction of the geolipid extract of Sample 528A-14-2, 120-125 cm (Pliocene). $n$ Alkanes are labeled by their carbon numbers. UCM = Unresolved Complex Mixture of branched and cyclic hydrocarbons. GC conditions: $20 \mathrm{~m}$ SE 54 glass capillary column, hydrogen carrier gas at $2 \mathrm{ml} / \mathrm{min}$., $70^{\circ}$ to $270^{\circ} \mathrm{C}$ at $4^{\circ} / \mathrm{min}$.

ed in a middle Miocene sample from DSDP Site 467 off the California coast (McEvoy et al., 1981) and in a Pleistocene sample from DSDP Site 364 in the Angola Basin (Simoneit, 1979). In the Leg 74 samples, the retention index of this major chromatogram peak is 2408 , slightly greater than that of $n-C_{24}$. Combined gas chromatography-mass spectrometry was done by pooling the aliphatic hydrocarbon fractions of the four samples from Site 528 to ensure enough material; it showed that this large peak contained no compounds that were not hydrocarbons. Although molecular fragments characteristic of $n$-alkanes were found, they constituted a small portion of the fragmentogram of this peak, which evidently represents several hydrocarbons, one of which is $n-C_{24}$. The major part, however, is one or more branched/cyclic hydrocarbons which remain to be identified.

Although it is impossible to suggest the source of this major contribution to the aliphatic hydrocarbons of these sediments without knowing the molecular structure, two observations are possible. First, the presence of a large peak having a gas chromatograph retention time corresponding to $n-\mathrm{C}_{24}$ in sediments from the east- ern but not from the western South Atlantic (Leg 72; Meyers and Dunham, in press), is intriguing. Second, the downcore increase in the size of the $C_{24}$ component at Site 528 (Fig. 1) suggests a relationship to diagenesis and/or changing paleoenvironment. Further study of these hydrocarbon components is clearly necessary.

\section{Fatty Acids}

Distributions of the $n$-alkanoic acids in Figure 3 are similar to those reported in DSDP samples of Pleistocene through Miocene ages from other locations. In five of these six Leg 74 samples, distributions are bimodal, with maxima centered upon the $\mathrm{C}_{16}$ and $\mathrm{C}_{26}$ components. Boon et al. (1979) described fatty acid distributions of organic-carbon-rich samples of Pleistocene, Pliocene, and Miocene ages from Site $\mathbf{3 6 2}$ on the Walvis Ridge. Total fatty acid extracts are dominated by evenchain-length components, and $\mathrm{C}_{16}$ and $\mathrm{C}_{26}$ are the major $n$-alkanoic acids. A similar fatty acid distribution was found in a Pleistocene sample having a lower organic carbon content from Site 364 north of the Walvis Ridge in the Angola Basin (Simoneit, 1979). Other bimodal acid distributions have been reported in Pleistocene through Miocene DSDP samples having $\sim 1-3 \%$ organic carbon from the California Borderland (Simoneit and Mazurek, 1981) and the Middle America Trench (Brassell et al., 1982). Such bimodality is evidence of multiple biological sources of fatty acids. The $\mathrm{C}_{14}, \mathrm{C}_{16}$, and $\mathrm{C}_{18}$ components indicate a general origin from algae, bacteria, and other plants, whereas the $\mathrm{C}_{24}, \mathrm{C}_{26}$, and $\mathrm{C}_{28}$ components are products of land plants (Simoneit, 1978).

Ratios of selected fatty acid components are given in Table 2. Even/odd ratios are high and indicate the strong biogenic, as opposed to diagenetic, character of the $n$-alkanoic acid distributions in these sediments. Ratios of $n-\mathrm{C}_{26}$ to $n-\mathrm{C}_{16}$ acids are presented as a simple measure of the relative amounts of land-derived versus aquatic or bacterial acids. These ratios are quite variable and could be interpreted as evidence of fluctuations in the relative contributions of terrigenous and marine organic matter over time. However, poor agreement exists between the $n-\mathrm{C}_{26} / n-\mathrm{C}_{16}$ acid ratios and the $n-\mathrm{C}_{29} / n-\mathrm{C}_{17}$ alkane ratios. Because the hydrocarbon ratios are more reliable source indicators and less sensitive to postdepositional alteration, it is more likely that the acid ratios reflect the amount of degradation experienced by the acids. In general, shorter-chain acids such as $n-\mathrm{C}_{16}$ are more easily destroyed by sediment microbes than are

Table 2. Ratios of geolipid components extracted from sediment samples from Leg 74.

\begin{tabular}{|c|c|c|c|c|c|c|}
\hline $\begin{array}{l}\text { Geolipid } \\
\text { Fraction }\end{array}$ & $\begin{array}{c}525 \mathrm{~A}-6-5 \text {, } \\
120-125 \mathrm{~cm}\end{array}$ & $\begin{array}{l}525 \mathrm{~A}-8-6 \text {, } \\
120-125 \mathrm{~cm}\end{array}$ & $\begin{array}{c}528-1-3 \\
120-125 \mathrm{~cm}\end{array}$ & $\begin{array}{c}528 \mathrm{~A}-5-2 \\
120-125 \mathrm{~cm}\end{array}$ & $\begin{array}{l}528 \mathrm{~A}-14-2, \\
120-125 \mathrm{~cm}\end{array}$ & $\begin{array}{l}528 \mathrm{~A}-23-2 \\
120-125 \mathrm{~cm}\end{array}$ \\
\hline \multicolumn{7}{|l|}{ Aliphatic hydrocarbons } \\
\hline Pristane/Phytane & 1.03 & 1.04 & 1.00 & 1.07 & 1.26 & 1.10 \\
\hline Pristane $/ n-\mathrm{C}_{17}$ & 0.46 & 0.61 & 0.45 & 0.64 & 0.83 & 0.26 \\
\hline$n-\mathrm{C}_{29} / n-\mathrm{C}_{17}$ & 0.34 & 3.48 & 0.60 & 9.63 & 0.90 & 1.37 \\
\hline \multicolumn{7}{|l|}{ Alkanoic acids } \\
\hline$n-\mathrm{C}_{26} / n-\mathrm{C}_{16}$ & 2.17 & 0.57 & 0.01 & 0.53 & 0.32 & 2.04 \\
\hline Even/odd $n$-Acids ${ }^{\text {a }}$ & 18.2 & 8.2 & 14.5 & 8.0 & 8.6 & 16.9 \\
\hline
\end{tabular}



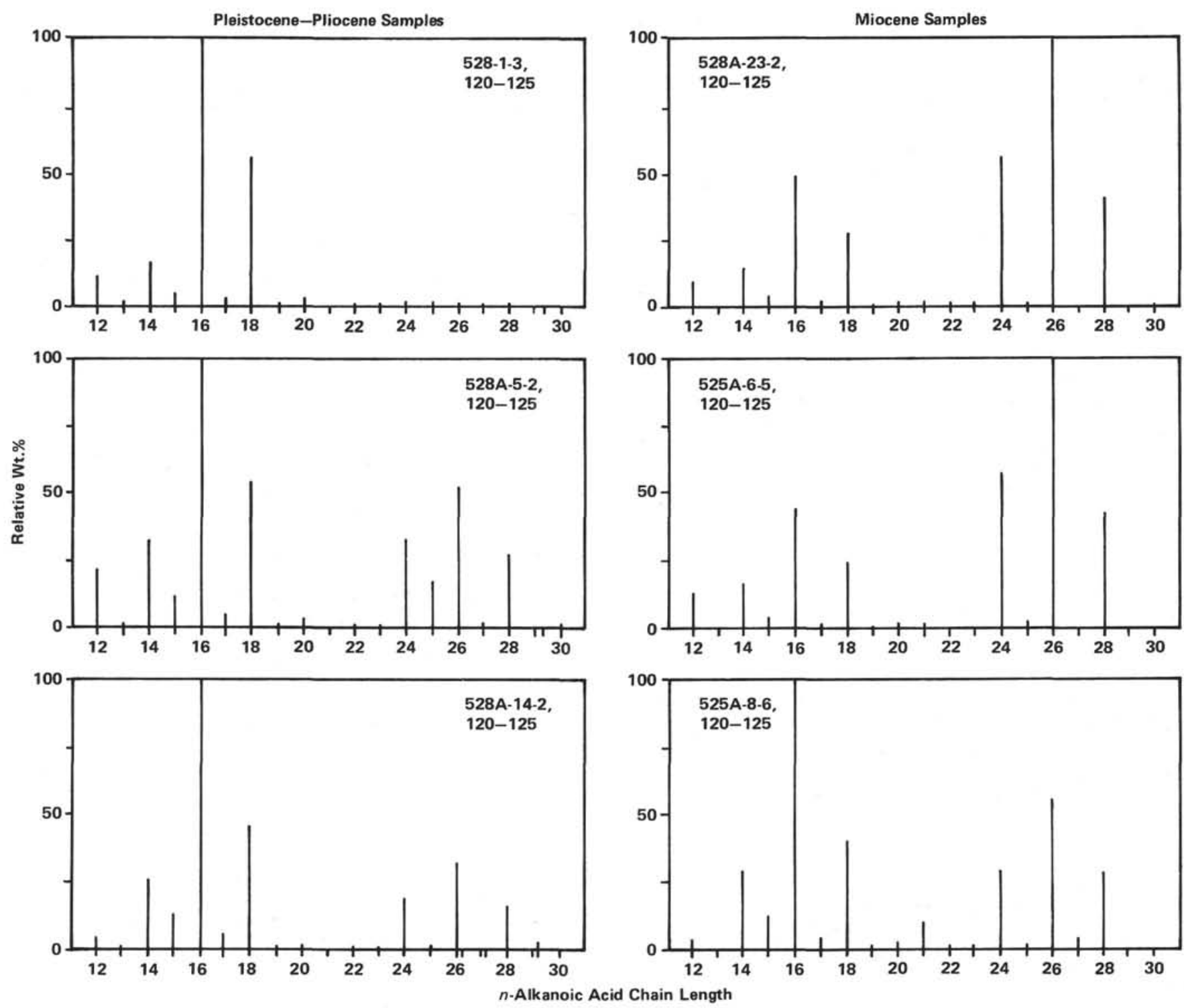

Figure 3. Histograms of $n$-alkanoic acid distributions normalized to the major component in each sample (100\%).

longer-chain acids in early stages of burial (Cranwell, 1981). Hence, the bimodal acid distributions in these Leg 74 sediments probably indicate a residuum of terrigenous, long-chain acids plus the presence of secondary, shorter-chain acids of a presumed microbial origin.

Evidence exists that degradation of shorter-chain acids continues with time of burial. Relative amounts of longer-chain acids increase with increasing sub-bottom depth at Site 528 (Fig. 3 and Table 2). Because the proportions of shorter-chain, aquatic $n$-alkanes and longerchain, terrigenous $n$-alkanes do not show a similar depth trend, the change in $n$-alkanoic acid compositions indicates a continuing preferential loss of shorter-chainlength acids over time.

One sample, 528-1-3, 120-125 cm, contains relatively little terrigenous fatty acids. This distribution is similar to the $n$-alkanoic acid distributions found in organiccarbon-lean Pleistocene and Pliocene samples from DSDP Sites 515, 516, and 517 in the western South Atlantic (Meyers and Dunham, in press). Such fatty acid distributions may represent either essentially complete degradation of all originally deposited components and their replacement by bacterial lipids or, alternatively, good preservation of original lipids which are predominantly marine in origin. The presence of an important contribution of long-chain-length, terrigenous $n$-alkanes in Sample 528-1-3, 120-125 cm, (Fig. 1) shows that extensive degradation and replacement of fatty acids by bacteria is the best explanation in this case.

\section{SUMMARY AND CONCLUSIONS}

1. Low concentrations of organic carbon in Pleistocene, Pliocene, and Miocene samples from Sites 525 and 528 on the Walvis Ridge indicate that incorporation of organic matter in sediments at these locations took place in oxygenated bottom water conditions and under surface waters having low biological productivity.

2. The distributions of $n$-alkanes contain important amounts of land-plant components which imply terrigenous contributions to the organic matter contents of 
these sediments. Because of the bottom morphology at these sites, eolian transport is the probable input process.

3. Distributions of aliphatic hydrocarbons and $n$-alkanoic acids and downcore decreases in total organic carbon concentrations provide evidence of microbial reworking of organic components deposited in the sediments at these sites.

\section{ACKNOWLEDGMENTS}

We thank Orest E. Kawka for performing $\mathrm{CHN}$ analyses. We are grateful to Robert Cunningham, Brian J. Eadie and Bernd R. T. Simoneit for suggesting improvements to this manuscript.

\section{REFERENCES}

Boon, J. J., van der Meer, F. W., Schuyl, P. J. W., de Leeuw, J. W., Schenck, P. A., and Burlingame, A. L., 1979. Organic geochemical analyses of core samples from Site 362, Walvis Ridge, DSDP Leg 40. In Bolli, H. M., Ryan, W. B. F., et al., Init. Repts. DSDP, Suppl. to Vols. 38, 39, 40, and 41: Washington (U.S. Govt. Printing Office), 627-737.

Brassell, S. C., Eglinton, G., and Maxwell, J. R., 1982. Preliminary lipid analyses of two Quaternary sediments from the Middle America Trench, southern Mexico transect, Deep Sea Drilling Project Leg 66. In Watkins, J. S., Moore, J. C., et al., Init. Repts. DSDP, 66: Washington (U.S. Govt. Printing Office), 557-580.

Cobler, R., and Dymond, J., 1980. Sediment trap experiment on the Galapagos spreading center, equatorial Pacific. Science, 209: 801-803.

Cranwell, P. A., 1981. Diagenesis of free and bound lipids in terrestrial detritus deposited in a lacustrine sediment. Org. Geochem., 3: 79-89.

Degens, E. T., and Mopper, K., 1976. Factors controlling the distribution and early diagenesis of organic material in marine sediments. In Riley, J. P., and Chester, R. (Eds.), Chemical Oceanography (Vol. 6): New York (Academic Press), 59-113.

Demaison, G. J., and Moore, G. T., 1980. Anoxic environments and oil source bed genesis. Org. Geochem., 2:9-31.

Didyk, B. M., Simoneit, B. R. T., Brassell, S. C., and Eglinton, G., 1978. Organic geochemical indicators of palaeoenvironmental conditions of sedimentation. Nature, 272:216-222.

Diester-Haass, L., 1978. Sediments as indicators of upwelling. In Boje, R., and Tomczak, M. (Eds.), Upwelling Ecosystems: Berlin (Springer Verlag), pp. 261-281.

Doran, T., and Johnson, P. G., 1979. Examination of potential geochemical contaminants in Leg 48 material. In Montadert, L., Roberts, D. G., et al., Init. Repts. DSDP, 48: Washington (U.S. Govt. Printing Office), 1157-1160.

Gagosian, R. B., Peltzer, E. T., and Zafiriou, O. C., 1981. Atmospheric transport of continentally derived lipids to the tropical North Pacific. Nature, 291:312-314.
Hinga, K. R., Sieburth, J. McN., and Heath, G. R., 1979. The supply and use of organic material at the deep-sea floor. J. Mar. Res., 37: 557-579.

Knauer, G. A., and Martin, J. H., 1981. Primary production and carbon-nitrogen fluxes in the upper $1,500 \mathrm{~m}$ of the northeast $\mathrm{Pa}$ cific. Limnol. Oceanogr., 26:181-186.

McEvoy, J., Eglinton, G., and Maxwell, J. R., 1981. Preliminary lipid analyses of sediments from Sections 467-3-3 and 467-97-2. In Yeats, R. S., Haq, B. U., et al., Init. Repts. DSDP, 63: Washington (U.S. Govt. Printing Office), 763-774.

McIver, R., 1975. Hydrocarbon occurrences from JOIDES Deep Sea Drilling Project. Proc. Ninth World Pet. Congr.: London (Applied Science Publ.), pp. 269-280.

Meyers, P. A., and Dunham, K. W., in press. Organic geochemistry of Quaternary sediments from Deep Sea Drilling Project Leg 72, South Atlantic Ocean. In Barker, P. F., Carlson, R. L., Johnson, D. A., et al., Init. Repts. DSDP, 72: Washington (U.S. Govt. Printing Office).

Müller, P. J., 1977. C/N ratios in Pacific deep-sea sediments: Effects of inorganic ammonium and organic nitrogen compounds sorbed by clays. Geochim. Cosmochim. Acta, 41:765-776.

Rullkötter, J., Flekken, P., and Welte, D. H., 1980. Organic petrography and extractable hydrocarbons of sediments from the northern Philippine Sea, Deep Sea Drilling Project Leg 58. In Klein, G. deV., Kobayashi, K., et al., Init. Repts. DSDP, 58: Washington (U.S. Govt. Printing Office), 755-762.

Simoneit, B. R. T., 1977. Organic matter in eolian dusts over the Atlantic Ocean. Mar. Chem., 5:443-464.

1978. The organic geochemistry of marine sediments. In Riley, J. P., and Chester, R. (Eds.), Chemical Oceanography (Vol. 7): London (Academic Press), 233-311.

, 1979. Lipid analyses of sediments from Site 364 in the Angola Basin, DSDP Leg 40. In Bolli, H. M., Ryan, W. B. G., et al., Init. Repts. DSDP, Suppl. to Vols. 38, 39, 40, and 41 : Washington (U.S. Govt. Printing Office), 659-662.

Simoneit, B. R. T., and Mazurek, M. A., 1981. Organic geochemistry of sediments from the southern California Borderland, Deep Sea Drilling Project Leg 63. In Yeats, R. S., Haq, B. U., et al., Init. Repts. DSDP, 63: Washington (U.S. Govt. Printing Office), 837-853.

Stevenson, F. J., and Cheng, C.-N., 1972. Organic geochemistry of the Argentine Basin sediments: Carbon-nitrogen relationships and Quaternary correlations. Geochim. Cosmochim. Acta, 36:653-671.

Suess, E., 1980. Particulate organic carbon flux in the oceans-surface productivity and oxygen utilization. Nature, 288:260-263.

Suess, E., and Müller, P. J., 1980. Productivity, sedimentation rate and sedimentary organic matter in the oceans-II. Elemental fractionation. Biogeochim. Mat. Org. Interfac. Eau-Sed. Marin., pp. 17-26.

Waples, D. W., and Sloan, J. R., 1980. Carbon and nitrogen diagenesis in deep sea sediments. Geochim. Cosmochim. Acta, 44: 1463-1470. 